\title{
RE-THINKING OF POPULAR CULTURE STUDIES AS INTERDISCIPLINARY SUBJECT
}

\author{
Min Bahadur Pun*
}

\begin{abstract}
This paper discusses the emergence of popular culture as an interdisciplinary subject of research. The simplest way to define the term 'popular culture's is a culture widely favored by many people. It refers to beliefs, practices and objects widely shared among people. Some of the examples of popular culture are romance novels, science fiction, photography, pop music, journalism, advertising, television, video, computers, Internet, etc. The study of popular culture entered a new phase in the cultural and intellectual history with the establishment of the Center for Contemporary Cultural Studies (CCCS) led by Richard Hoggart and Stuart Hall. Two things happened to the study of popular culture as an interdisciplinary subject: (1) the study of popular culture has included wide range of issues (2) scholars have intellectual freedom in this field, and they show no interest in establishing clear boundaries around it. Popular culture is always defined in contrast to other conceptual categories such as folk culture, mass culture, dominant culture, and working class culture. Thus, popular culture becomes the 'Other' for them, which largely depends on the context of use. Lastly, the paper discusses the role of popular culture in history, anthropology, sociology and literary theories. In theory, the study of popular culture is always around the debate on postmodernism. It assumes that postmodern culture no longer recognizes the distinction between high culture and popular culture.
\end{abstract}

\section{INTRODUCTION}

The study of popular culture has undergone a dramatic change during the last phase of the twentieth century. Following the social upheavals of the 1960s, popular culture is taken more seriously as a terrain of academic enquiry and has also helped to change the outlooks of more established disciplines. Conceptual barriers between so called high and low culture have broken down, there is an explosion in scholarly interest in popular culture, which encompasses such diverse mediums as comic books, television and the Internet. Popular culture studies as known today was developed in the late 1970s and 80s. These days, anthropologist, historians, sociologist, and literary scholars have posed intellectual challenges to basic assumption in their own fields that had previously barred close attention to popular forms.

In the past twenty years these intellectual developments, shaped by the general cultural upheaval of the 1960s, undoubtedly helped change the concepts of conventional disciplines and define a number of hybrid fields, including communication and cultural studies. The conceptual difference between 'high' culture and popular culture has broken down. Such developments in popular culture studies have forced "a fundamental rethinking of cultural divisions as well as a broadening of intellectual inquiry" (Bathrick, 330). Art and literary critics

* Mr. Pun is Associate Professor in English at Prithvi Naryan Multiple Campus, Pokhara, Nepal. 


\section{RE-THINKING OF POPULAR CULTURE...}

have in common recognized high culture and popular culture as human social practices. This approach has slowly influenced thinking about culture in the humanities. Scholars have also realized how much the traditional division of high and popular culture has been a political division rather than an aesthetic and traced the mutual influence of high and popular culture. Similarly, they have taken popular culture as a field of political and social conflict and as a weapon for political move.

The redefinition of the study of popular culture has made problematic of earlier views of mass culture as degraded and elite culture as elevating. Instead, the redefinition has recognized the power of the ordinary, reject the ideological distinction between mass culture and elite culture, and ask question about the role of popular culture in political and social life.

The legitimacy of popular culture as a subject for study in universities and a subject of inquiry for serious scholars has grown enormously at the present. In both the social sciences and humanities, the study of popular culture has been transformed as "otherness which is always absent/present when we use the term 'popular culture"' (Storey, 1). Thus, popular culture will always powerfully affect the connotations brought into the play, which depends on the context of use.

In this period of rethinking, popular culture is not easy to define. Popular culture refers to the beliefs and practices, and the objects through which they are organized, and are widely shared among the people of different beliefs. This includes folk beliefs, practices and objects rooted in local traditions, and mass beliefs, practices and objects generated in political and commercial centers. It includes elite cultural forms that have been popularized as well as popular forms that have been elevated to the museum tradition. In this way, some of the subtleties of new cultural theories can be achieved and the array of studies have made traditional conceptions of popular culture as "vulgar, base and trivial" (Smith, 16).

Studies of popular culture is creating a truly interdisciplinary literature, scholars continue to speak of their own disciplinary backgrounds and come upon the scene of popular culture not entirely fresh but shaped by particular bents, traditions, and theories of their own fields. And a great deal of the difficulty rises from the attitude of ambivalence the absent/present other; as such, popular culture becomes the others. For instance, mass culture, high culture, working class culture, folk culture, etc. may be employed popular culture's others, it will carry into the definition of popular culture a specific theoretical and political inflection (Storey, 14). No single discipline has a monopoly on the study of popular culture; no discipline represents a single best approach. Each sees a different part of the elephant, instead.

This paper deals with the emergence of rethinking of popular culture by demonstrating in a range of disciplines the rich resources and significant problems for inquiry that have opened up. This is a limited selection of the present study; the study does not cover all the areas of study. The attempts have been made to represent a range of key figures and key ideas, to include pieces that draw attention to a variety of popular cultural forms, and provide examples of different theoretical and disciplinary perspectives. 


\section{CULTURE IN THE HUMANITIES AND SOCIAL SCIENCES}

The discovery of disciplinary underpinnings of popular culture studies is precisely important because popular culture has become an interdisciplinary subject of research. The study of popular culture has embraced wide range of issues with array of methods that got diffused to many. Many of the researchers using intellectual freedom of the field show no interest in establishing clear boundaries around it. In fact, they have rebelled against the traditional territorial arrangement of disciplines and have in many cases loath to draw a new set of territorial lines. The field is not easily characterized by either its perimeter or its center. The boundaries are not clear. By looking at how popular culture analysis has developed in history, anthropology, sociology and literary studies, novices to the field can see more clearly how the intellectual traditions and politics of diverse fields have helped shape the issues within popular culture studies.

Historians, in general, have given more sustained scholarly attention to popular culture than members of any other discipline. Scholars specializing in the nineteenth and early twentieth centuries have most frequently looked at popular culture to understand the consequences of the industrial revolution, especially the role of culture in the development of the working class, the significance of the new commercial culture developing in the period, and the new uses of culture as a means of social control.

The study of popular culture in history has had a range of uses and benefits for historians as well as diversity of analytic forms. The study of neglected groups, championed by early modernist but visible among other specialists, has corrected the historical misconceptions and brought to the forefront of historical research areas like social and cultural history that have broadened the charges of historians. The studies of cultural politics initiated mostly by specialist in the nineteenth-century working class or women's history have made it decisively clear that one should never again think that ordinary people have been unimportant to political history; they have been visibly engaged in the cultural realm in shaping and resisting the exercise of power.

Anthropological and other approaches of social sciences to the study of culture had little impact on central understandings of culture in the humanities. Anthropological approach to the study of human societies has been essential to the revival disciplines of popular culture studies. Interest in understanding contemporary popular and mass cultural forms has hardly been universal in anthropology, and its tradition of cultural relativism has not until recently tempered a disciplinary disdain for modern mass culture.

The anthropological focus on exotic and traditional cultures has typically blinded anthropology to the contemporary popular culture of the primitive groups as these groups encountered modernizing influences. Anthropologists did not see mass cultural forms such as Indian films or tourist art as worthy of scholarly attention. If they were recognized at all, they were seen as symptoms of the breakdown of noble tradition, impurities in the cultural practice rather than the practice itself. In this way, even the relatively egalitarian discipline of anthropology carved out its own academic niche while joining art and literary criticism in condemning modern popular culture. Even anthropology tended to 


\section{RE-THINKING OF POPULAR CULTURE...}

praise folk culture for its authenticity and demean mass culture for its commercial origins and purposes. But two movements have encouraged anthropologists to apply their "long-standing cultural relativism to the analysis of modern forms of popular culture" (Mukerji \& Schudson, 18). We label these, loosely, the structuralist and interpretivist wings in anthropology.

The structuralist stream, inspired by the conceptual tools of linguistics and the work of French anthropologist Claude Levi-Strauss, has affected the anthropological research on a wide range of subjects from kinship structures to mythology. Levi-Strauss and his followers work from the assumption that language is a fundamentally structured and structuring part of culture. Similarly, the interpretivist tradition of anthropological theory has been much more strongly connected to popular culture studies within anthropology itself as well as in a number of the social sciences. This tradition can be traced most of all to Clifford Geertz, an American anthropologist. His celerity is today probably as pronounced in history, sociology, communication and even literature departments as in anthropology. He elaborates a notion of a 'cultural system' that strictly distinguishes it from the social system.

In sociology, more than in any other discipline, it was taken for granted that popular culture could be a legitimate subject of study. In the early twentieth century, when American sociology was primarily a native discipline, linked to Protestant social reform and to a strong emphasis on 'social problems', popular culture entered unobtrusively into sociological studies.

Sociologists, particularly those influenced by a Marxist tradition, have drawn attention to the connections between culture and social class. They have, more than anthropologists or literary scholars, centered work on the socio-cultural dimensions of social differentiation and social stratification. In the Marxistinfluenced tradition, this means primarily an emphasis on the relations between culture and class; in the American tradition, it is just as likely to examine the relations between culture and other social forms of differentiated power, notably ethnicity and gender.

Then, a central lesson of the new studies of popular culture is that a radical distinction between high culture and popular culture cannot be maintained. Aspects of popular culture become high culture over time; for instance, cultural forms such as Charles Dickens, folk art, early manufactured furniture, and jazz have now become the established art forms. Aspects of high culture become popular culture, for instance, Pachelbel's "Canon in D" and Handel's Messiah, both of them was once known as classics, have become the popular cultural forms over time. Thus, the borderline of elite and popular culture is patrolled, and the fences are maintained, for identifiably social and political rather than purely aesthetic, purposes.

The above considerations, no doubt, link up with new studies in literature and the arts on 'canonization'. Literary scholars are increasingly reflective about the extent to which their own activity is not abstractly critical but concretely political - that is what counts as a piece of 'literature' and it depends very much on what individuals and institutions connected with the dominant 
gender and dominant social classes. What counts as a masterpiece is a social and political process, not an exercise of pure reason.

\section{POPULAR CULTURE AND LITERARY THEORIES}

The new theoretical approaches to the study of culture no longer exclude topics like popular ceremonies or consumer goods from the range of possible research subjects. Literary theory that focuses on relations between texts, their producers, and their audiences, and can conclude that a text is definable only by these relationships, necessarily reconsiders romance novels and science fiction and television soap operas and other denigrated literary forms as acceptable subjects for study. Of course, this is not a matter of purely intellectual development detached from its social setting. Not only have the theoretical views in the different fields influenced one another, but all have been shaped by the changing politics of academic life since the 1960s.

The most dramatic rethinking of popular culture has been initiated by literary critics, many of whom have left behind altogether traditional allegiances to high culture as the privileged subject matter of serious criticism. They have led a series of critical revolutions with a proliferating set of theoretical schools such as structuralism, semiology, poststructuralism, deconstruction, discourse theory and a startling opacity of terminology that has pushed towards "multiperspectivism" (Bathrick, 323). But within this brave new world of literary theory are new tools of critical analysis and new outlooks on the nature of culture, broadly understood, that reach far beyond the confines of literature departments.

Popular culture in literary or broadly, cultural criticism can be traced to both right-wing and left-wing dissatisfaction with the cultural inclinations of the general population. On the right, anxiety about democratic and egalitarian movements and about increasing working-class participation in politics was accompanied by disapproval of the mass culture. The left-wing as well as rightwing deplored the influence of mass-produced commercial culture. Where the Right blamed the low level of mass culture on the tastes of the masses, the Left blamed it on elite efforts to domesticate a potentially unruly population. On the Right, this brand of criticism did not develop in any systematic way, but on the Left, it became a sophisticated set of critical perspectives in the hands of the Frankfurt School.

There is a turning point in the study of popular culture with the establishment of the Center for Contemporary Cultural Studies (CCCS) in Britain in the 1960s. Raymond Williams including other key figures like Stuart Hall and Richard Hoggart, offered a program, the notions of a 'base' determining a 'superstructure', for a Marxist theory of culture, establishing the 'cultural studies' movement. And the field of communication has become a center for the kind of popular cultural studies. In the United States, this is also increasingly true, as students of communication are influenced by various literary theorists, notably Mikhail Bakhtin, and British cultural studies especially Stuart Hall and Raymond Williams. Antipathy of the founders of Frankfurt School to mass culture of the twentieth century made attempts to analyze contemporary culture using this critical perspective more difficult for Marxists. 


\section{RE-THINKING OF POPULAR CULTURE...}

New Criticism is identified as the most original Anglo-American contribution to literary theory. It arose in the $1930 \mathrm{~s}$ as a specifically antihistoricist, anticontextual reading of texts. New Criticism asserted that knowing the author's intensions or, indeed, anything at all about the author and the world in which he or she wrote was irrelevant to deciphering the meaning of texts. The message was in the text itself, and the good reader could discover it without reference to external clues.

New Criticism seemed to have little to offer students of popular culture. After all, its practitioners were concerned with developing techniques for distinguishing good from bad literature, in which all the components of the text contributed to "the reconciliation of opposites that constitutes its poetic function" (Robey, 85) and did not generally deign to touch mass culture because it was by definition less closely tied to a distinctive authorial style. But still, their approach to reading had its counterpart in film studies, in the guise of 'auteur theory'. Critics working within this tradition tried to explain individual films by reference to the corpus of the director.

Serious study forms of popular culture as popular culture, using techniques of literary criticism, had to wait for the semiotics of Roland Barthes. Barthes was among the early structuralists to use Saussurian linguistics as a means of cultural analysis. He went one step beyond most structuralists. He did not simply use linguistic techniques for analyzing patterns of literary writing; he proposed to use them for studying non-literary works like film, photography, clothing, and other popular forms like food and boxing.

For literary theorists trying to understand artworks of any sort means that authors are to be set aside as objects of study, and new objects are to be given center stage. Popular cultural forms are impersonally developed and "often regarded as and 'ideological machine'" (Bennett, 348). They must be accounted for with an analysis of the systems by which languages are mobilized. With the exception of the British School of Marxists, who have been particularly interested in working-class resistance to structural systems of control, little room is left in structuralist theories for concerted action, expressive or political. This is one of the problems of structuralism that helped spur the development of poststructuralist theories.

If no one is the author, perhaps everyone is the author. The central tenet of poststructuralist analyses is that texts are multivocal. Texts are seen as having variety of potential meanings, none of which is the real meaning to be derived by some superior reader. The Frankfurt School, Marxism, New Criticism, and structuralist theories all have taken it for granted that the purpose of criticism is to discover 'the' meaning of the text. In contrast, poststructuralists have generally been more interested in the variability of readings as "a momentary 'fix' between two moving layers" (Selden 71) than in the perfect ability of the reading process. All texts, the poststructuralists effectively reach, are 'intertexual'; and just as they subtly or openly, intentionally or unconsciously, allude to or incorporate other texts, so they make themselves inevitably open to multiple readings.

From this viewpoint, the critic loses his or her special expertise. The act of criticism is an act of reading. This means that popular reading of popular 
culture are just as interesting a subject matter for poststructualist analysis as readings by critics within elite culture. Jacques Derrida argues, for instance, that the world of writing has its own life, and its textuality is part of how it communicates. It is spatial and visual, not simply aural. So language use on paper has its own meanings, problems, and possibilities and becomes "a new metaphysical ground of being" (Docker, 130). This enables analysts like Derrida and his followers to seek out the conceptual contradictions in writing, contradictions so severe that written work is its own criticism, or, as one school of poststructuralism says, writing 'deconstructs' itself into an "undercidable scasster of opposed significations" ('Poststructuralism', 261).

With the revival of Freudian thinking in France based on the work of Jacques Lacan, critics have asked more about how human needs are addressed through culture. Like Lacan, a number of poststructuralists like Foucault and Barthes have also asked questions about the psychological factors that pervade the process of reading.

Sex and power have been particularly important categories in feminist theories, in which culture can be made and used. And they look for an "authentically female culture" (Bennett 348). Similarly, feminists have also contended that language is by its nature political as well sensual and establishes systems of power in its every use.

Foucault raises many of these issues on the author. His analysis suggests that we have so long kept standard ideas about authorship in large part because without them the cultural critic could no longer identify great work by its great author. That would be dangerous because it would upset the system of power, which is "gained through discourse" (Selden, 102), in language, known as discourse theory, including the stratified relationship of elite to popular culture. Popular culture is often 'authorless,' unless like film, it is elevated by the identification of its 'real' author (the director). It is precisely because Foucault's analysis of literary authorship unravels so revealingly the politics of cultural stratification that it is so important to students of popular culture.

Foucault calls into question what it means to be an author, but critics like Wolfgang Iser and Stanley Fish pointedly raise the issue of what it means to be a reader. Reader response theory developed before poststructuralism and without the concern for the multivocal quality of texts themselves. But the poststructuralist movement of deconstruction is a theory of reading that subverts the structuralist view and proposes a creative reading of any text as a play of differences that generate innumerable, mutually contradictory, but totally 'undecidable' meanings.

Poststructuralism in linguistic has parallels with the movement known as postmodernism in literature and arts. Posmodernism, for Storey, is a term current inside and outside the academic study of popular culture (146). Thus, popular culture has a direct relation with this movement because both have the common interest in their approaches.

The development of postmodern theory emerges from United States and Britain in the early 1960s, through its theorization in the work of Jean-Francois 


\section{RE-THINKING OF POPULAR CULTURE...}

Lyotard, Jean Baudrillard and Fredric Jameson. Postmodernism involves not only the counter traditional experiments of modernism but also diverse attempts to break away from modernist forms which has to overthrow the elitism of modernist 'high art' by returning to the models of 'mass culture' in film, television, newspaper cartoons, and popular music. In this connection, Peter Brooker in his introduction to Modernism/Postmodernism writes: "Postmodernism splices high with low culture, it raids and parodies past art, it questions all absolutes, it swamps reality in a culture of recycled images, it has to do with deconstruction and consumerism, television, the end of communism... the rise of the information society" (qtd. in Hutcheon).

Thus, one prominent tendency is to subvert the hierarchical distinctions between 'high art or literature' and the traditionally 'lower' forms that appeal to a much larger body of consumers, or to devote no more attention to elite canonical literature than to popular fiction and romances, magazine writing, journalism, and advertising, together with other arts that have mass appeal such as comics, film, television, video, and all forms of popular music. Prominent is the undertaking to transfer to the center of cultural study such hitherto 'marginal' or 'excluded' subjects as the literary, artistic, and intellectual productions of women, the working class, ethnic groups, and colonial, postcolonial, and Third-World cultures; for instance, Storey says, "the study of popular shows that 'studying' popular culture can be a very serious business indeed-serious political business" (171).

The implications of this position are probably most evident in the studies of canonization and canonicity that are now popular in literary studies. In one elegant example, Jane Tompkins has written of the social, economic, and political underpinnings of the rise of Nathanial Hawthorne's writings to 'masterpiece' status. She challenges the common place notion of a 'classic' as a text that retains its value even though times change. She argues that a 'classic' is in constant change:

Rather than being the repository of eternal truths, they embody the changing interests and beliefs of those people whose place in the cultural hierarchy empowers them to decide which works deserve the name of classic and which do not. For the idea of 'the classic' itself is no more universal or interest-free than the situation of those whose business it is to interpret literary works for the general public. (qtd. in Mukerji \& Schudson, 53)

Thus, the interpretation leaves the students of popular culture wondering if the elite culture/popular culture distinction and all the elaborate barricades and buildings and temples erected to sustain it, has finally been revealed as a house of cards.

In general, literary scholars, art and music historians, and cultural critics were the most committed of all academics to elitist concepts of culture. Indeed, defining taste and value was in many ways their reason for existence. Thus, they seemed to be most uninterested of all to study popular culture. And this may help explain why the changes in literary theory have been the most far-reaching of any considered here. The traditional tools of literary scholarship seemed shockingly at odds with the antielitist tone of so much contemporary art and writing, the very subject of scholarship seemed to be rejecting its institutionalized study. The revolution in theories of interpretation could not help addressing new questions about the purpose of cultural criticism itself. 


\section{CONCLUSION}

The disciplinary origins of the new research in popular culture result from the broad reassessments of the nature of culture within these fields. Many scholars have had to suspend beliefs in fundamental normative prescriptions of Western culture, a difficult move in its requirements of careful theoretical reasoning but a rewarding one in opening up for study of a vast range of human activities.

As definitions of what objects are important for cultural analysis have changed, popular culture has found legitimacy for the very reasons it was previously derided. This has made it central to any understanding of Western societies and though as John Docker, in his book Postmodernism and Popular Culture: A Culture History, says, "In the postmodern world, we might say, it is never easy to distinguish between the mainstream and the oppositional, the conforming and the unconventional, the majority and minority view- between centres and margins that are ever shifting and uncertain" (163).

The irony of the situation is that popular culture, so often described by academics as insignificant, and alien to the Great Tradition of Western culture, has arrived in the present intellectual environment as a fascinating and revolutionary object for academic thought. That is why, although the rethinking of popular culture may be embedded in analysis of jokes, romance novels, and the treatment of pets, it is not just about these subjects. It is also a commentary on broad intellectual changes initiated by scholars who, in struggling to see Western culture without being totally blinded by its assumptions, began to think about and reject the taboos that had kept thinkers away from everyday culture. They have bravely redefined the role and value of popular amusements and, in doing so transformed their thinking.

In summing up the above discussion, it can be said that it has drawn attention to some of the basic points in the debate about the relationship between postmodernism and popular culture. The main point is that postmodern culture no longer recognizes the distinction between high and popular culture. For some this is to celebrate as an end to an elitism constructed on arbitrary distinctions of culture; for others, it is a reason to despair as the final victory of commerce over culture. Ironically, the debate on the role of popular culture in the study of literature is one of the intellectual terrains from where the interdisciplinary area of study begins.

\section{WORKS CITED}

Bathrick, D. 1992. "Cultural Studies." Introduction to Scholarship: In Modern Languages and Literatures. $2^{\text {nd }}$ ed., Joseph Gibaldi (ed.). New York: MLA.

Bennett, Tony. 1995. "Popular culture and 'the turn to Gramsci." Approaches to Media: A Reader. Oliver Boyd-Barrett and Chris Newbold (eds.). London: Arnold.

Docker, J. 1994. Postmodernism and Popular Culture: A Cultural History. Melbourne: Cambridge University Press.

Hutcheon, L. 2007. "The Shift from Modernism to Postmodernism." The Politics of Postmodernism 1996. Liverpool John Mores University. 


\section{RE-THINKING OF POPULAR CULTURE..}

Mukerji, C. \& Michael, S. 1991. "Introduction: Rethinking Popular Culture." Rethinking Popular Culture: Contemporary Perspectives in Cultural Studies. Chandra Mukerji and Michael Schudson (eds.). Berkeley: California.

"Poststructuralism." 1993. A Glossary of Literary Terms. $6^{\text {th }}$ ed. By M.H. Abrams. Bangalore: Prism Books.

Robey, D. 1986. "Anglo-American New Criticism." Modern Literary Theory: A Comparative Introduction. $2^{\text {nd }}$ ed. Ann Jefferson and David Robey (eds.). London: B.T. Batsford.

Selden, R. 1989. A Reader's Guide to Contemporary Literary Theory. $2^{\text {nd }}$ ed. New York: Harvester Wheatsheaf.

Smith, M. J. 2002. Culture: Reinventing the Social Sciences. New Delhi. Viva.

Storey, J. 2001. Cultural Theory and Popular Culture: An Introduction. $3^{\text {rd }}$ ed. Harlow: Princeton. 